\title{
PENGELOLAAN PEMBELAJARAN BERBASIS DISKUSI UNTUK MENINGKATKAN HASIL BELAJAR SISWA KELAS XI DI MAN 2 PONTIANAK
}

\author{
Dony Andrasmoro ${ }^{1}$, Siti Nurlaila ${ }^{2}$, \\ ${ }^{1}$ Program Studi Pendidikan Geografi \\ Fakultas Ilmu Pendidikan dan Pengetahuan Sosial IKIP PGRI Pontianak \\ Jalan Ampera Nomor 88 Pontianak-78116, Telepon (0561) 748219 Fax. (0561) 6589855 \\ ${ }^{2}$ Madrasah Aliyah Negeri (MAN) 2 Pontianak \\ Jl. Ahmad Yani No. 9 Pontianak, Pontianak Selatan \\ ${ }^{1}$ Alamat e-mail: donny.andrasmara@gmail.com
}

\begin{abstract}
Abstrak
Tujuan penelitian ini untuk mengetahui penggunaan metode pembelajaran diskusi interaktif untuk meningkatkan hasil belajar siswa kelas XI IPS 2 Madrasah Aliyah Negeri (MAN) 2 Pontianak dan untuk mengetahui peningkatan hasil belajar siswa pada materi AMDAL dengan metode pembelajaran diskusi interaktif. Metode penelitian ini Action Research (AR) dengan bentuk penelitian Classroom Action Research (CAR). Hasil penelitian dengan pemenfaatan metode diskusi interaktif dapat meningkatkan hasil belajar siswa materi AMDAL di kelas. Hasil analisis siklus I menunjukkan hasil refleksi kegiatan diskusi masih belum tercipta kepercayaan diri, terkesan pasif. Hasil kegiatan pembelajaran siklus I belum menunjukkan pemerataan siswa aktif dan hasil siklus II siswa termotivasi karena diskusi dilakukan dengan penampilan studi kasus video AMDAL sehingga hasil peningkatan belajar cukup baik 63,33 , kentuntasan $58 \%$, hasil siklus II meningkat 73,84 , persentasi kentuntasan $82 \%$, hasil siklus II lebih besar dari persentasi kentuntasan dengan ketegori baik. Dampak ketuntasan hasil belajar adalah aspek retention rate of knowledge siswa.
\end{abstract}

Kata Kunci: Pembelajaran, Diskusi, Hasil belajar

\begin{abstract}
The purpose of this research was to find out, the use of interactive discussion learning methods to improve student learning outcomes of class XI IPS 2 Madrasah Aliyah Negeri (MAN) 2 Pontianak and to find out the improvement of student learning outcomes in AMDAL material with interactive discussion learning methods. This research method is Action Research with the form of Classroom Action Research. The results of research with the use of interactive discussion methods can improve student learning outcomes of AMDAL material in the classroom. The results of the first cycle analysis showed that the results of the reflection of the discussion activities had not yet created confidence, seemed passive. the results of the first cycle learning activities have not shown active student equity and the results of cycle II students are motivated because the discussion was carried out with the appearance of an AMDAL video case study so that the results of improved learning were 63.33, 58\% completion, cycle II results increased 73.84, completion percentages $82 \%$, the results of the second cycle are greater than the percentage of completion with good categories. The impact of completeness of learning outcomes is the retention rate of knowledge of students.
\end{abstract}

Keywords: Learning, Discussion, Learning outcomes 


\section{PENDAHULUAN}

Pendidikan merupakan kegiatan seseorang atau sekolompok orang untuk mencapai tujuan pendidikan.Kegiatan bantuan dalam pendidikan dapat berupa pengelolaan pendidikan dan dapat pula berupa kegiatan seperti bimbingan, pengajaran dan atau latihan. Berdasarkan Undang-undang No 20 tahun 2003 tentang pendidikan nasional (SISDIKNAS) pasal 3 disebutkan bahwa:

"Pendidikan nasional berfungsi untuk mengembangkan kemampuan dan membentuk watak serta peradaban bangsa yang bermartabat dalam rangka mencerdaskan kehidupan bangsa yang bertujuan untuk mengembangkan potensi peserta didik agar menjadi manusia yang beriman dan bertakwa kepada Tuhan Yang Maha Esa, berakhlak mulia, sehat, cakap, kreatif, berilmu, mandiri dan menjadi warga negara yang demokratis serta bertanggung jawab"

Sekolah merupakan salah satu lembaga pendidikan formal yang mempunyai tanggung jawab untuk mendidik siswanya oleh sebab itu di sekolah diadakan proses belajar mengajar sebagai suatu realisasi tujuan pendidikan, sebagai penanggung jawab dalam proses belajar mengajar di sekolah khususnya di dalam kelas adalah guru. Seorang guru memiliki tanggung jawab untuk membimbing siswa dalam proses belajar mengajar agar tercipta proses pembelajaran yang efektif dan efisien. Pembelajaran merupakan pusat kegiatan belajar mengajar yang terdiri dari guru dan siswa yang bermuara pada peningkatan intelektual, kedewasaan emosional, ketinggian spiritual, kecakapan hidup dan keagungan moral.

Belajar dan pembelajaran merupakan suatu elemen yang sangat penting dalam rangka mewujudkan kualitas yang bermutu baik dalam proses maupun mencapai lulusan (output) dalam dunia pendidikan. Proses belajar dan pembelajaran sangat tergantung dalam kemampuan guru dalam merancang dan melaksanakan pembelajaran. Pembelajaran yang dilaksanakan sangat efektif dan efisien tentu akan memberikan kontribusi yang sangat signifikan bagi siswa, sebaliknya pembelajaran yang dilaksanakan dengan tidak baik dan sesuai maka akan berdampak pada belajar yang kurang afekti, mengakibatkan potensi siswa sukar untuk dikembangkan dan ditingkatkan prestasinya. 
Pembelajaran merupakan bagian atau elemen yang memiliki peran sangat dominan untuk mewujudkan kualitas, baik proses pembelajaran maupun lulusan pendidikan. Pembelajaran juga memiliki pengaruh yang menyebabkan kualitas pendidikan menjadi rendah. Artinya pembelajaran sangat tergantung dari kemampuan guru dalam melaksanakan atau mengemas proses pembelajaran. Pembelajaran yang di laksanakan secara baik dan tepat akan memberikan kontribusi sangat dominan bagi siswa. Sebaliknya pembelajaran yang dilaksanakan dengan cara yang tidak baik akan menyebabkan potensi siswa sukar dikembangkan atau diberdayakan.

Kemampuan yang harus dimiliki guru, sebagai salah satu unsur pendidik, adalah mampu melaksanakan tugas profesionalnya adalah memahami bagaimana peserta didik belajar dan bagaimana mengorganisasikan proses pembelajaran yang mampu mengembangkan kemampuan dan membentuk watak peserta didik, serta memahami tentang bagaimana siswa belajar. Untuk dapat memahami proses belajar yang terjadi pada diri siswa, guru perlu nguasai hakikat dan konsep dasar belajar. Dengan menguasai hakikat dan konsep dasar tentang belajar diharapkan guru mampu menerapkan dalam kegiatan pembelajaran, karena fungsi utama pembelajaran adalah memfasilitasi tumbuh dan berkembangnya belajar dalam diri peserta didik.

Aspek kondisi pembelajaran di kelas XI IPS 2 Madrasah Aliyah Negeri (MAN) 2 Pontianak pada mata pelajaran Pendidikan Geografi pada materi menganalisis sebaran dan pengelolaan sumber daya kehutanan, pertambangan, kelautan, dan pariwisata sesuai prinsip-prinsip pembangunan berkelanjutan, diupayakan pengelolaan pembelajaran yang sesuai dengan situasi materi dan kondisi siswa dimana belum terpenuhinnya target guru dalam penilaian hasil pembelajaran.

Perlu pendekatan metode pembelajaran supaya tercapai hasil belajar yang lebih efektif dan meningkatkan hasil yang signifikan yaitu dengan pendekatan metode membuat siswa untuk turut aktif dalam pembelajaran. Satu di antara metode pembelajaran yang tepat untuk membangun menambah pemahaman dan pengatahuansecara langsung serta meningkatkan interaksi siswa dengan siswa lain 
dan mengajarkan kepada siswa saling mengerti dan saling menghormati pendapat yang dikemukakan dengan suanan belajar akrab, gembira, terbuka dan tercapainya tujuan pembelajaran yaitu metode pembelajaran diskusi. Menurut Nagita (2013: 2) "Metode diskusi merupakan metode pembelajaran yang melibatkan komponen, mulai dari siswa dalam kolompok, maupun guru yang memiliki peran penting dalam mengkondisikan kelas waktu diskusi kolompok. Diskusi berlangsung dalam suasana terbuka, setiap siswa bebas mengemukakan ide-ide nya tanpa merasa ada tekenan dari teman atau dari gurunya'. Sedangkan menurut Mulyasa dalam Prianto Tri Puji (2006:79) diskusi kelompok adalah suatu proses percakapan yang teratur, yang melibatkan sekelompok orang dalam interaksitatap muka yang bebas dan terbuka, dengan tujuan berbagi informasi pengalaman, mengambil keputusan atau memecahkan suatu masalah.

\section{METODE}

Moleong (2013 : 238) menjelaskan "Penelitian tindakan adalah cara melakukan penelitian dan berupaya bekerja untuk memecahkan masalah pada saat bersamaan".Mahmud (2011: 199), menjelaskan bahwa "Action Research pada hakikatnya merupakan rangkaian "riset-tindakan-riset-tindakan", yang di lakukan secara siklus dalam rangka memecahkan masalah sampai masalah tersebut terpecahkan. Dalam penelitian ini, metode yang dianggap sesuai oleh peneliti adalah menggunakan Action Research (AR) atau penelitian tindakan.

\section{HASIL DAN PEMBAHASAN}

Penelitian di laksanakan di Kelas XI IPS 2 Madrasah Aliyah Negeri (MAN) 2 pontianak. Kegiatan pratindakan dilakukan untuk mengawali penelitian tindakan kelas, dengan tujuan untuk mengetahui hasil belajar awal siswa pada materi menganalisis sebaran dan pengelolaan sumber daya kehutanan, pertambangan, kelautan, dan pariwisata sesuai prinsip-prinsip pembangunan berkelanjutan. Kegiatan pra tindakan dilakukan oleh guru dan kolaborasi dosen PDS yaitu dari perencanaan pelaksanaan pembelajaran, dan mengadakan evaluasi untuk mengatahui sejauh mana pemahaman dan pengatahuan siswa pada materi 
menganalisis sebaran dan pengelolaan sumber daya kehutanan, pertambangan, kelautan, dan pariwisata sesuai prinsip-prinsip pembangunan berkelanjutan. Untuk perencanaan kegiatan pembelajaran pratindakan ini mengacu kepada RPP yang digunakan oleh guru dan dosen PDS sebelumnya mengacu pada Silabus dan pelaksanaan pratindakan dilakukan pada tanggal 12 Agustus 2015.

\section{Grafik 1. Persentasi Ketuntasan Belajar Siswa Pada Pra Tindakan}

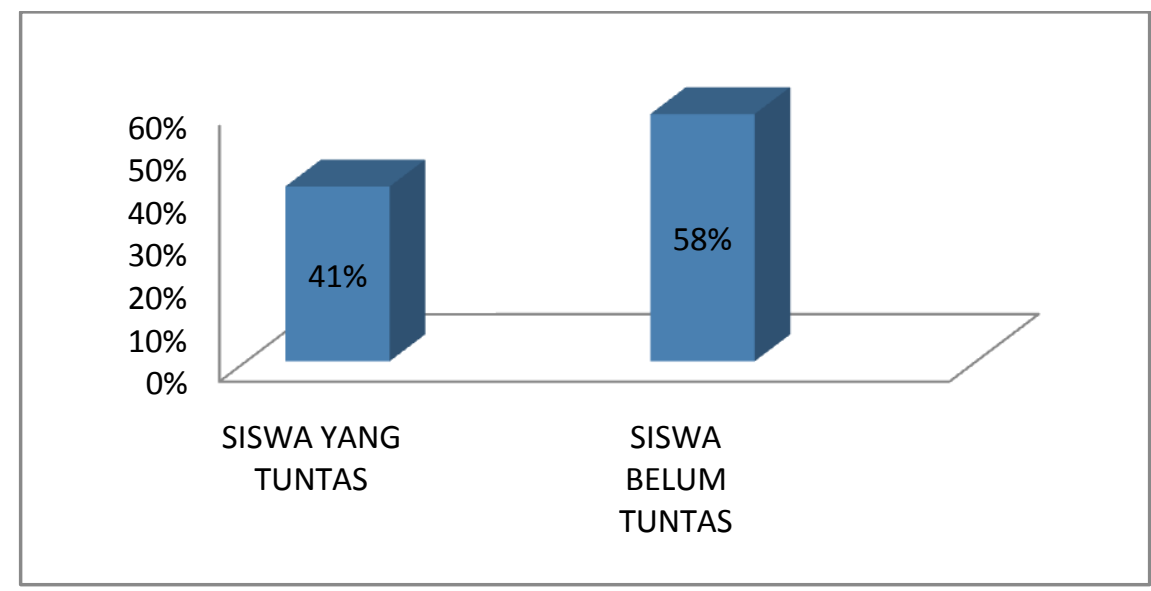

Berdasarkan data hasil belajar siswa pra tindakan pada materi materi menganalisis sebaran dan pengelolaan sumber daya kehutanan, pertambangan, kelautan, dan pariwisata sesuai prinsip-prinsip pembangunan berkelanjutan, dapat diketahui bahwa hanya terdapat 16 orang siswa saja yang memenuhi nilai Keteria Ketuntasan Minimal (KKM) dengan persentasi ketuntasan sebanyak $41 \%$ dari jumlah keseluruhan 36 orang siswa pada pelaksaan berlangsungnya pembelajaran pra tindakan. Sedangkan hasil rata-rata siswa yang didapat dari keseluruhan jumlah nilai siswa pada pra tindakan adalah 52,56. Dari hasil tes pada materi materi menganalisis sebaran dan pengelolaan sumber daya kehutanan, pertambangan, kelautan, dan pariwisata sesuai prinsip-prinsip pembangunan berkelanjutan dapat disimpulkan bahwa tingkat pengatahuan siswa terhadap sub pokok bahasan Analisis Mengenai Dampak Lingkungan (AMDAL) tergolong rendah.

Berdasarkan permasalahan yang dirumuskan pada pendahuluan serta hasil data yang telah didapat maupun yang telah dianalisis dari hasil pelaksanaan setiap 
siklusnya pada penggunaan metode pembelajaran diskusi pada sub materi AMDAL di kelas XI IPS 2 MAN 2 Pontianak dengan konsep prosedur penelitian tindakan kelas yang dilakukan sebanyak dua siklus. Berikut akan dirumuskan hasil penelitian berupa data yang telah didapat selama dilakukan pelaksanaan penelitian secara keseluruhanyaitu, hasil dari pratindakan, siklus I dan siklus II.

Berdasarkan data dari hasil pengamatan terhadap guru dalam melaksanakan penggunaan metode pembelajaran diskusi pada sub materi AMDAL di kelas XI IPS 2 MAN 2 Pontianak setiap siklusnya menunjukan peningkatan, berdasarkan hasil persentasi lembar observasi guru pada siklus I hanya mencapai70\% dan pada siklus II hasil dari lembar observasi guru menunjukan terjadinya peningkatan dengan persentasi ketuntasan mencapai $82 \%$. Hasil tersebut menunjukan guru dalam melaksanakan pembelajaran berjalan dengan afektikpada penggunaan metode pembelajaran diskusi dalam menyajian Sub materi AMDAL.

Berdasarkan data dari lembar observasi siswa dalam pelaksanaan penelitian terhadap penggunaan metode diskusi dan hasil kinerja kolompok siswa. Berdasarkan hasil pengamatan kegiatan siswa selama penggunaan metode diskusi dari keseluruhan aspek lembar observasi siswa siklus I, persentasi ketuntasan mencapai $65 \%$ dan terjadi peningkatan dalam penggunaan metode diskusi siswa pada siklus II mencapai 79\%. Berdasarkan hasil data lembar observasi penilaian hasil kinerja kolompok siswa dalam penggunaan metode diskusi siklus I dengan persentasi ketuntasan hanya mencapai $64 \%$ dan hasil penilaian kinerja kolompok siswa siklus II menunjukan peningkatan mencapai $80 \%$.

Berdasarkan data nilai hasil belajar siswa sebagai pengukur ketercapaian dan peningkatan dalam pelaksanaan penelitian pada materi biosfer dari pelaksanaan peneliti pratindakan, siklus I dan siklus II selama penggunaan metode pembelajaran diskusi untuk meningkatkan hasil belajar siswa pada sub materi AMDAL di kelas XI IPS 2 MAN 2 Pontianak.Dari nilai hasil belajar siswa pada pratindakan rata-rata yang diperoleh hanya 52,56 dengan persentasi ketuntasan belajar siswa hanya mencapai $41 \%$, hasil nilai hasil belajar siswa siklus I rata-rata yang diperoleh hanya 63,33 dengan persentasi ketuntasan belajar sebanyak 58\%, 
dan hasil nilai hasil belajar siswa siklus II rata-rata yang diperoleh mencapai 73,84 persentasi ketuntasan belajar sebesar $82 \%$

Berdasarkan hasil selama penelitian yang telah deskripsikan di atas, maka untuk lebih jelasnya mengatahui hasil peningkatan pada Penggunaan metode pembelajaran diskusi untuk meningkatkan hasil belajar siswa pada materibiosfer sub materi AMDAL di kelas XI IPS 2 MAN 2 Pontianak dalam pelaksanaan penelitian pratindakan, siklus I, dan siklus II dapat dilihat pada tabel sebagai berikut.

Tabel 1. Hasil Belajar Siswa Dari Keseluruhan Tindakan Penelitian

\begin{tabular}{|c|c|c|c|c|c|c|}
\hline \multirow{2}{*}{ No } & Siklus & \multirow{2}{*}{$\begin{array}{c}\text { Jumlah } \\
\text { Siswa }\end{array}$} & \multicolumn{2}{|c|}{ Nilai } & \multirow{2}{*}{$\begin{array}{c}\text { Nilai Rata- } \\
\text { Rata }\end{array}$} & Persentase \\
\cline { 4 - 5 } & & & $\leq 70$ & $\mathbf{7 0}$ & & \\
\hline 1 & Pratindakan & 39 & 23 siswa & 16 siswa & 52,56 & $41 \%$ \\
\hline 2 & Siklus I & 39 & 14 siswa & 23 siswa & 63,33 & $58 \%$ \\
\hline 3 & Siklus II & 39 & 7 siswa & 32 siswa & 73,84 & $82 \%$ \\
\hline
\end{tabular}

\section{Grafik 2. Peningkatan Persentasi Ketuntasan Dan Rata-Rata Hasil Belajar Siswa Pada Materi Biosfer}

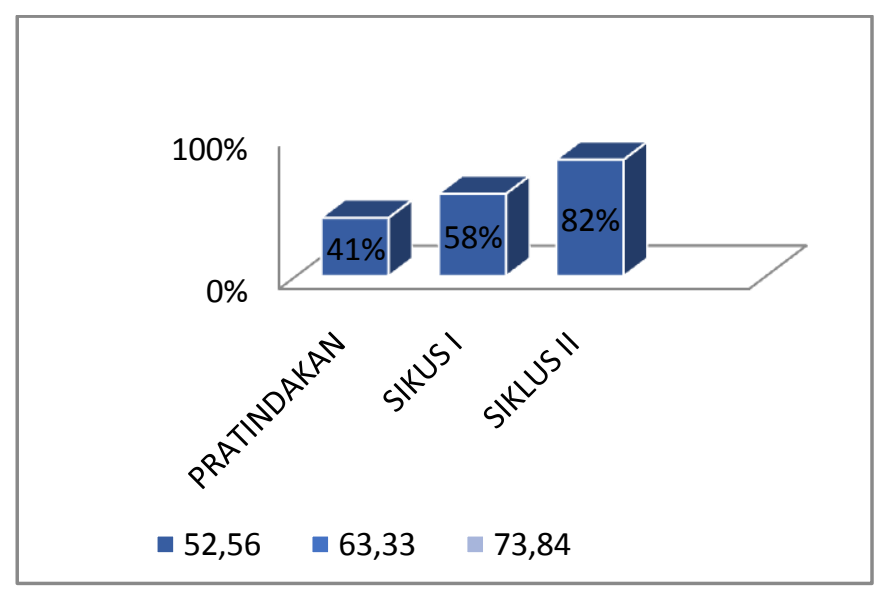

Berdasarkan tabel dan grafik terhadaphasil belajar siswa dari keseluruhan tindakan penelitian diatas bahwa Penggunaan metode pembelajaran diskusi untuk meningkatkan hasil belajar siswa pada sub materi AMDAL di kelas XI IPS 2 MAN 2 Pontianak secara keseluruhan dari hasil pratindakan, hasil siklus I, dan hasil siklus II dapat disimpulkan bahwa hasilsetiap siklusnya mengalami peningkatandilihat dari rata-rata dan persentasi disiklus II dapat dikatakan nilai 
siswa memenuhi keteria ketuntasan minimal (KKM) secara persentasi ketuntasan telah mencapai angka yang dikehendaki yaitu diatas dari $75 \%$. Guru dan peneliti sepakat tidak akan melanjutkannya kembali kesiklus selanjutnya karena tujuan penelitian sudah tercapai selama melakukan penelitian sebanyak dua siklus. Maka penelitian ini telah selesai dilaksanakan dan dinyatakan berhasil.

\section{SIMPULAN}

Berdasarkan dari hasil penelitiaan, secara umum dapat disimpulkan bahwa penggunaan metode pembelajaran diskusi dapat meningkatkan hasil belajar siswa pada materi AMDAL di kelas XI IPS 2 MAN 2 Pontianak. Sedangkan secara khusus dalam penelitian ini, dapat disimpulkan dari rumusan sub masalah penelitian yang telah disusun, adapun hasil dari rumusan sub masalah penelitian ini sebagai berikut: sub materi AMDAL di kelas XI IPS 2 MAN 2 Pontianak dengan penggunaan metode pembelajaran diskusi di kelas XI IPS 2 MAN 2 Pontianak menunjukan peningkatan setiap siklusnya. Pada pratindakan hasil ratarata yang diperoleh yaitu 52,56 dengan persentasi kentuntasanhanya $41 \%$ yang dikategorikan kurang, hasil pada siklus I meningkat dengan rata-rata 63,33 dan persentasi kentuntasan sebesar 58\%, masih dikategorikan kurang, dan pada siklus II meningkat dengan rata-rata mencapai 73,84 dan persentasi kentuntasan mencapai $82 \%$ yang menunjukan hasil pada siklus II lebih besar dari persentasi kentuntasan yang dikendaki pada ketegori baik.

\section{UCAPAN TERIMA KASIH}

Terima Kasih penulis ucapkan kepada Direktorat Jendral Pembelajaran dan Kemahasiswaan Kementrian Riset, Teknologi, dan Pendidikan Tinggi (Belmawa RISTEKDIKTI) dengan kegiatan Revitalisasi LPTK melalui hibah Penugasan Dosen di Sekolah (PDS) 2018 yang mendanai kegiatan ini. Terimakasih juga kami sampaikan kepada lembaga IKIP PGRI Pontianak yang telah memfasilitasi kegiatan ini. 


\section{DAFTAR PUSTAKA}

Anonim. 2008. "Sistem Pendidikan Nasional" dalam https://fadlolymasterteacher. wordpress.com. Diakses Tanggal 15 Oktober 2018.

Nagita (2013). Penerapan Metode Diskusi Untuk Meningkatkan Prestasi Belajar Bahasa Indonesia Siswa Kelas III Yappi Tegal Weru, Tepus, Tepus Gunungkidul Tahun Pelajaran 2012/2013. (http://digilib.uinsuka.ac.id/9203/. Diakses 10 Oktober 2018.

Moleong, J.L 2013. Metodologi Penelitian Kualitatif. Bandung: Remaja Rosda karya Offset.

Mahmud, 2011. Metode Penelitian Pendidikan. Bandung: CV. Pustaka Setia.

Prianto,Tri Puji. 2006. "metode diskusi macromedia flash untuk peningkatan hasil belajar alat ukur mekanik" dalam Jurnal Taman Vokasi Vol. 5, No. 1, Juni 2017, PortalGaruda.org(Terakreditasi). Jakarta. 